\title{
The Fe-loop experiments provide new constraints for the olivine-melt Fe2+- Mg partitioning model improvement
}

$$
\begin{aligned}
& \text { STEPAN KRASHENINNIKOV } \\
& \text { KNA }^{1,2}, \text { ALEXANDER }^{3} \\
& \text { BORISOV }^{3}, \text { ALINA KOSHLYAKOVA }^{1}, \text { VALENTINA G. }^{1,4} \text { AND ALEXANDER V. SOBOLEV }^{4,5} \\
& \text { BATANOVA }^{1,4}
\end{aligned}
$$

${ }^{1}$ Vernadsky Institute of Geochemistry and Analytical Chemistry RAS

${ }^{2}$ Leibniz University of Hannover, Institute of Mineralogy

${ }^{3}$ Institute of Geology of Ore Deposits, Petrography, Mineralogy and Geochemistry RAS

${ }^{4}$ Université Grenoble Alpes

${ }^{5}$ Institute of Earth Sciences (ISTerre), University Grenoble Alpes

Presenting Author: spkrash09@gmail.com

Numerous studies show, that the $\mathrm{Fe}-\mathrm{Mg}$ exchange coefficient, $\mathrm{K}_{\mathrm{d}}^{\mathrm{Fe} 2+-\mathrm{Mg}}=\left(\mathrm{X}_{\mathrm{FeO}}{ }^{\mathrm{OL}} / \mathrm{X}_{\mathrm{FeO}}{ }^{\text {melt }}\right) /\left(\mathrm{X}_{\mathrm{MgO}}{ }^{\mathrm{OL}} / \mathrm{X}_{\mathrm{MgO}}{ }^{\text {melt }}\right)$ is mostly independent of melt composition. In a recent study, [1] presented the results of experiments on olivine-melt equilibrium conducted in a wide $\mathrm{fO}_{2}$-temperature-pressure range both with dry and water-containing melts, which support the negligible effects of pressure, temperature, and melt composition on this coefficient.

The goal of the present study was to check if $\mathrm{K}_{\mathrm{d}}^{\mathrm{Fe} 2+-\mathrm{Mg}}$ is compositionally independent and improve existing models. We produced more than 100 pairs of coexisting olivine and silicate melts of a wide compositional range. Hawaiian, Icelandic and Norilsk picrites used as starting compositions. Modified lamproites from the Gaussberg volcano represent highly alkaline melts. To exclude the uncertainty following from ferric/ferrous determination, the experiments were conducted at $\mathrm{fO}_{2}$ well below IW buffer, where the fraction of $\mathrm{Fe}^{3+}$ in total $\mathrm{Fe}$ in silicate melts is negligible. The samples on iron wire loops were equilibrated with $\mathrm{H}_{2}-\mathrm{CO}_{2}-\mathrm{Ar}$ gas mixture in $1 \mathrm{~atm}$ vertical tube furnace in the temperature range $1200-1500{ }^{\circ} \mathrm{C}$. To keep a high level of alkalis in silicate melts in such reduced conditions a few runs were conducted with crucible-supported loop technique [2].

On average, the experimental $\mathrm{K}_{\mathrm{d}}^{\mathrm{Fe} 2+-\mathrm{Mg}}$ values are in excellent agreement with those found in Blundy's (2020) experiments. From this point of view, our experiments strongly support previous findings. However, our data clearly demonstrates that the melt composition does affect $\mathrm{K}_{\mathrm{d}}^{\mathrm{Fe} 2+-\mathrm{Mg}}$ values. The most popular and frequently used models of $\mathrm{Fe}-\mathrm{Mg}$ partitioning tested and compared based on our experimental dataset (Fig. 1).

We suggest the new equation for $\mathrm{K}_{\mathrm{d}}^{\mathrm{Fe} 2+\mathrm{Mg}}$. The equation supports the minor effect of temperature, but the compositional dependence on $\mathrm{Si}, \mathrm{Ti}, \mathrm{Al}, \mathrm{Ca}, \mathrm{K}$ and $\mathrm{Na}$ of this coefficient is evident. It can be used for more precise estimates of parental or primary melt compositions than with previously published models. The new equations suggested for $\mathrm{K}^{\mathrm{Fe} 2+}$ and $\mathrm{K}^{\mathrm{Mg}}$ partition coefficients may be used as possible geothermometers for high magnesian and highly alkaline mafic melts.

[1] Blundy J., et al. (2020) CMP 175:103.

[2] Borisov, A., et al. (2006) $A M$ 91, 762-771. 